\title{
GEOPHYSICAL CHARACTERIZATION OF AQUIFER SYSTEMS USING VERTICAL ELECTRICAL SOUNDING METHOD IN DEMSA, NORTHEAST NIGERIA
}

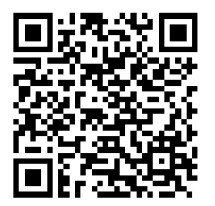

\author{
Saleh Mustapha Babagana ${ }^{*}{ }^{\square}$ iD , Satendra Sharma ${ }^{2}$ (iD \\ *1, 2 Department of Physics, Yobe State University Damaturu, P.M.B 1144, Damaturu, Nigeria
}

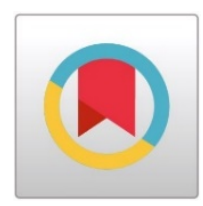

DOI: https://doi.org/10.29121/granthaalayah.v8.i11.2020.2379

Article Type: Research Article

Article Citation: Saleh Mustapha Babagana, and Satendra Sharma. (2020). GEOPHYSICAL CHARACTERIZATION OF AQUIFER SYSTEMS USING VERTICAL ELECTRICAL SOUNDING METHOD IN DEMSA, NORTHEAST NIGERIA. International Journal of Research GRANTHAALAYAH, 8(11), 175-184. https://doi.org/10.29121/granthaa layah.v8.i11.2020.2379

Received Date: 06 November 2020

Accepted Date: 30 November 2020

Keywords:

Resistivity Method

Aquifer Systems

Schlumberger Array

Demsa

Benue River

\section{ABSTRACT}

Electrical resistivity method using vertical electrical sounding (VES) technique and Schlumberger array was employed with the aim of delineating limits and types of aquifer system(s), and stratigraphic composition of the Demsa area, a confluence of Benue River in Northeast Nigeria. The result revealed that the hydrogeology of the area may be controlled by fractures (secondary porosity) developed in sedimentary units. Two aquifers, namely the upper alluvial aquifer and the confined deeper aquifer systems exist in the study area. The two aquifers occur at depths of $20.5-41 \mathrm{~m}$, and $43.8-78.9 \mathrm{~m}$ respectively, and are separated by a thin layer of poorly permeable clays and silts, ranged between $1.1-5.3 \mathrm{~m}$ in thickness. The lateral extent of the aquifer systems extend almost evenly across the area. The aquifers' thickness tends to decrease with increase in distance of VES station from the Benue River which suggested that the aquifer systems are probably recharged by direct escapement of the Benue River.

\section{INTRODUCTION}

Data scarcity on groundwater resources in developing countries affects proper management of the resources in terms of its suitability and sustainability for domestic and agricultural activities. Groundwater is becoming a reliable alternative to surface water system in Nigeria, hence understanding the concept of developing and managing the resources is an issue to reckon with. Demsa (the area of the present study) is one of such areas where data on groundwater and by extension hydrogeology is still limited with little or no scholarly records, despite significant portion of its inhabitants relying on groundwater supply for domestic and irrigation activities. The aim of the present study was to apply electrical resistivity method - vertical electrical sounding (VES) technique - to delineate limits and types of aquifer system(s), and stratigraphy composition of the Demsa area. It was also to fill in the vacuum of scarce data on groundwater and hydrogeology in developing countries. Electrical resistivity method, specifically the vertical electrical sounding method has proved effective in the field of groundwater and hydrogeology exploration.

(C) 2020 The Author(s). This is an open access article distributed under the terms of the Creative Commons Attribution License, which permits unrestricted use, distribution, and reproduction in any medium, provided the original author and source are credited. 
Electrical resistivity was carried out in the present study to investigate type and limits of aquifer systems, and stratigraphy composition of the study area with a view to bridge the gap of limited data on groundwater and hydrogeology in developing countries as Nigeria. A total of thirty four (34) VES points, covering about $9.57 \times 10^{5}$ Square Kilometer, were recorded and data acquired were processed using computer software (IX1D v3 Interpex) to investigate resistivity variation for characterization of stratigraphy composition and forms aquifer system(s) in and around the study area.

Various geophysical techniques have been employed in groundwater exploration to map out suitable points for sustainable boreholes development, and one of such techniques commonly used is the electrical resistivity method (Olawuyi and Abolarin, 2013). Electrical resistivity method basically reflects variation in groundwater resistivity. The electrical resistivity contracts existing between subsurface lithology are often adequate to delineate stratigraphy composition and characterization of aquiferous and non-aquiferous layers (Ginaya and Yagoob, 2017). Of all near surface geophysical methods, the electrical resistivity method has been widely applied for groundwater exploration (Joseph Olakunle Coker, 2012).

\section{STUDY AREA}

The present study area lies between $9^{0} .15 \mathrm{~N}$ to $9^{0} .60 \mathrm{~N}$, and $11^{0} .70 \mathrm{E}$ to $12^{0} .30 \mathrm{E}$ which covers an area of about $9.57 \times 10^{5}$ Square Kilometer. Demsa is a catchment area of Benue River with a number of waterways across. The study area covers a total of seventeen (17) VES Stations wherein, thirty four (34) VES points were recorded. Kpasam, Bali and Bille are VES stations to the southwest, Bange, Dilli, Borrong and Mbula to the northeast, just by the Benue River. Other stations are Dowaya, Farai, New Demsa, Old Demsa, and Yelwa. Kokumso, Ngbolung, Dong, Lawaru and Bakin Dewi are VES stations along waterways. Fig. 1; shows a reference map of the study area indicating VES points at VES stations, waterways, and the Benue River. The map was design in QGIS software, using global positioning system (GPS) data obtained at the field.

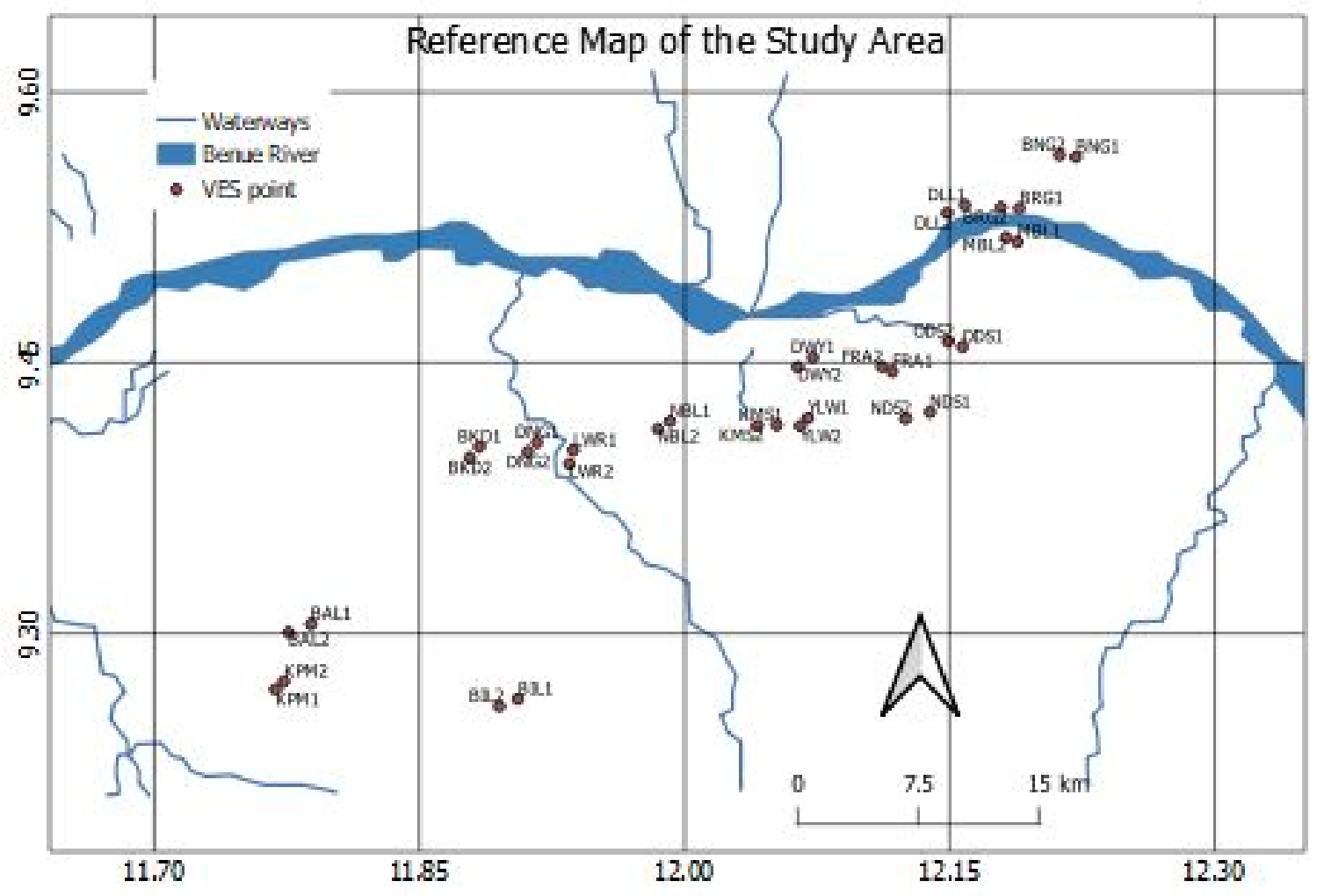

Figure 1: Reference map of the study area showing positions of VES points 
Saleh Mustapha Babagana, and Satendra Sharma

\subsection{GEOLOGICAL CONSIDERATION}

Demsa, the study area, lies on Cretaceous sedimentary unit of the Yola Arm of Upper Benue Trough, the Bima Sandstone. The Bima Sandstone at the study area indicates the base of sedimentary succession in the Upper Benue Trough, and is sub-divided from base to top into three sandstone members of Lower Aptian/Albian Bima, Middle Albian Bima sandstone and Late Albian/Cenomanian Upper Bima Sandstone (Obiefuna, 2010). At the surface, the geologic units are composed of fine-medium grained sandstone to the north and south, and coarse grained sandstone to the northeast (Obiefuna, 2010). The stratigraphic composition of the Bima Sandstone consists mostly of alternating layers of poorly to moderately consolidated fine to coarse grained sandstone, clay-shale, siltstone and mudstone with average thickness in excess of 250 meters as seen from their outcrops in the field (Obiefuna, 2010). The Bima Sandstone of the study area alternates between light brown to reddish brown in colour and is highly cemented in most places of the area.

\section{MATERIALS AND METHODS}

Thirty-four (34) vertical electrical sounding were measured using Schlumberger array with AB/2 (current electrode spacing) varying from 2 to $200 \mathrm{~m}$, and MN (potential electrode spacing) varying between 1 and $40 \mathrm{~m}$. A total seventeen (17) VES Stations were carefully identified to appropriately cover the study area, with two (2) VES points measured in each of the VES stations. Using the Schlumberger array method, the MN spacings were kept in fixed positions while varying the $\mathrm{AB} / 2$ spacings. This was to allow for deeper penetrations of D.C signals for maximum coverage of stratigraphic composition of the study area. D.C current signals were injected into subsurface using resistivity meter, the ABEM SAS1000 gadget. The corresponding apparent resistivity of the subsurface strata were subsequently recorded and processed using computer software, the IX1D v3 Interpex to deduce lithology of the area in terms of resistivity, thickness, and number of layers. Another computer software, the Surfer 13, was used to processed contour maps of aquifers (water bearing layers), and 3D maps of the layers' thickness using XYZ data format. Kriging Gridding method was adopted in the XYZ data gridding with minimum contour 70 to 100 , and maximum contour of 380 to 400 in second and fourth layers respectively. In both the layers, X-direction spacing was $4.6 \times 10^{-3}$ with 100 nombers of nodes. The Z-transformation was linear. The thirty-four (34) VES points were KPM1, KPM2, BAL1, BAL2, BIL1, BIL2, DNG1, DNG2, BKD1, BKD2, LWR1, LWR2, NBL1, NBL2, KMS1, KMS2, and YLW1, YLW2 at Kpasam, Bali, Bille, Dong, Bakin-Dewi, Lawaru, Ngbolung Kokumso, and Yelwa VES stations respectively. Others were DWY1, DWY2, FRA1, FRA2, NDS1, NDS2, ODS1, ODS2, MBL1, MBL2, BRG1, BRG2, DLL1, DLL2, and BNG1, BNG2, at Dowaya, Farai, New-Demsa, Old-Demsa, Mbula, Borrong, Dilli, and Bange VES stations respectively.

Many studies have established the effectiveness of electrical resistivity sounding method in mapping and delineating groundwater potentials (Hubbard and Rubin, 2000; Maliva et al., 2015; Slater, 2007; Lachaal et al., 2012; Falgàs et al., 2011; Maliva et al., 2009; Singha et al., 2008; Lesmes and Friedman, 2005). The geophysical method is generally regarded fit for groundwater exploration (Cardiff et al., 2013; Bowling et al., 2006; 0 and A, 2018; Meyerhoff et al., 2014).

\section{RESULTS AND DISCUSSION}

The result from the geophysical survey is presented in Table 1, displaying such parameters as location of the VES points, resistivity and thickness of layers. Geophysical analysis of the result revealed four (4) geoelectric layers in most places of the study area. These layers are mostly sandy-soil, sandy-clay and sands, sandstones, clays, silts and gravels. The topmost layer has resistivity variation ranged between $176.54 \Omega \mathrm{m}$ at VES point DNG1 of Dong station, and $233.14 \Omega \mathrm{m}$ at VES MBL1 of Mbula station. The layer is mostly sandy (clay or soil). The thickness of the topmost layer ranged between $3.6-10.1 \mathrm{~m}$. The second layer revealed a resistivity variation ranging from $77.48 \Omega \mathrm{m}$ at VES point MBL2 in Mbula VES station, to about $381.61 \Omega \mathrm{m}$ at VES point BAL1 of Bali station. This resistivity variation suggest that the layer is water bearing, and by extension, existence of aquifer. Thickness of the second layer varies between $20.5-41 \mathrm{~m}$. The second layer is mostly sand and/or sandstone. The third layer is a thin layer of thickness ranged between $1.1-5.3 \mathrm{~m}$, with resistivity variation ranged between $14.13 \Omega \mathrm{m}$ and about $668.35 \Omega \mathrm{m}$. The fourth layer revealed a resistivity variation ranging from $100.01 \Omega \mathrm{m}$ at VES YLW1 of the Yelwa station, to about $441.26 \Omega \mathrm{m}$ at VES FRA1 in Farai station. The resistivity of this layer also suggests a layer of water bearing, hence the 
deep aquifer. The thickness of the fourth layer ranged between $43.8-78.9 \mathrm{~m}$. The fifth layer is a layer of high resistivity ranging between $1180.03 \Omega \mathrm{m}$ at VES KPM1 of the Kpasam station to about $2222.81 \Omega \mathrm{m}$ at VES BNG2 of the Bange station. The contour maps in Fig. 2 and 3 revealed the almost even distribution of resistivities of the two aquifer systems across the study area, while Fig 4 and 5 show 3D maps revealing the thickness variation of the water bearing layers, which suggest the likelihood of the aquifer systems getting recharged by direct escapement of the Benue River.

Table 1: The values of vertical electrical sounding (VES) parameters with locations are given in the table. The resistivity $(\rho)$ and thickness $(\mathrm{h})$ of layers are also given in $(\Omega \mathrm{m})$ and $(\mathrm{m})$ units, respectively.

The source of information is based on the field survey done by the researchers

\begin{tabular}{|c|c|c|c|c|c|c|c|}
\hline VES Point & Location & Longitude & Latitude & Layer & $\rho(\Omega \mathrm{m})$ & $h(m)$ & Lithology description \\
\hline \multirow[t]{5}{*}{ KPM1 } & Kpasam & 11.76850 & 9.26891 & 1 & 196.31 & 7.2 & Sandy-clays \\
\hline & & & & 2 & 88.72 & 22.6 & Sand \\
\hline & & & & 3 & 18.61 & 5.3 & Clay \\
\hline & & & & 4 & 103.25 & 43.8 & Shale \\
\hline & & & & 5 & 1180.03 & - & Sand/gravel \\
\hline \multirow[t]{5}{*}{ KPM2 } & Kpasam & 11.77333 & 9.27327 & 1 & 211.30 & 3.6 & Sandy-soil \\
\hline & & & & 2 & 97.61 & 26.0 & Sand \\
\hline & & & & 3 & 24.11 & 4.3 & Clay \\
\hline & & & & 4 & 123.40 & - & Shale \\
\hline & & & & - & - & - & - \\
\hline \multirow[t]{5}{*}{ BAL1 } & Bali & 11.78854 & 9.30523 & 1 & 200.01 & 5.5 & Sandy-soil \\
\hline & & & & 2 & 381.61 & 38.9 & Silt \\
\hline & & & & 3 & 31.20 & 4.8 & Clay \\
\hline & & & & 4 & 113.47 & - & Shale \\
\hline & & & & - & - & - & - \\
\hline \multirow[t]{5}{*}{ BAL2 } & Bali & 11.77598 & 9.30064 & 1 & 177.96 & 8.6 & Sandy-soil \\
\hline & & & & 2 & 112.58 & 33.0 & Sand \\
\hline & & & & 3 & 311.04 & 3.7 & Silt \\
\hline & & & & 4 & 131.02 & - & Shale \\
\hline & & & & - & - & - & - \\
\hline \multirow[t]{5}{*}{ BIL1 } & Bille & 11.90579 & 9.26359 & 1 & 218.11 & 7.5 & Sandy-soil \\
\hline & & & & 2 & 110.25 & 25.7 & Sand \\
\hline & & & & 3 & 16.23 & 5.3 & Clay \\
\hline & & & & 4 & 121.47 & - & Shale \\
\hline & & & & - & - & - & - \\
\hline \multirow[t]{5}{*}{ BIL2 } & Bille & 11.89519 & 9.25956 & 1 & 185.36 & 8.8 & Sandy-soil \\
\hline & & & & 2 & 101.33 & 39.8 & Sand \\
\hline & & & & 3 & 418.14 & 2.1 & Silt \\
\hline & & & & 4 & 124.78 & - & Shale \\
\hline & & & & - & - & - & - \\
\hline \multirow[t]{5}{*}{ DNG1 } & Dong & 11.91649 & 9.40592 & 1 & 176.54 & 7.6 & Sandy-clay \\
\hline & & & & 2 & 114.02 & 21.0 & Sand \\
\hline & & & & 3 & 15.12 & 1.8 & Clay \\
\hline & & & & 4 & 113.50 & - & Sand \\
\hline & & & & - & - & - & - \\
\hline \multirow[t]{4}{*}{ DNG2 } & Dong & 11.91129 & 9.40072 & 1 & 199.65 & 6.6 & Sand-clay \\
\hline & & & & 2 & 100.04 & 27.0 & Sand \\
\hline & & & & 3 & 386.21 & 1.7 & Silt \\
\hline & & & & 4 & 122.54 & - & Shale \\
\hline
\end{tabular}


Saleh Mustapha Babagana, and Satendra Sharma

\begin{tabular}{|c|c|c|c|c|c|c|c|}
\hline & & & & - & - & - & - \\
\hline \multirow[t]{5}{*}{ BKD1 } & Bakin Dewi & 11.88387 & 9.40344 & 1 & 201.47 & 4.9 & Sandy-soil \\
\hline & & & & 2 & 110.25 & 30.8 & Sand \\
\hline & & & & 3 & 15.63 & 3.8 & Clay \\
\hline & & & & 4 & 118.64 & - & Shale \\
\hline & & & & - & - & - & - \\
\hline \multirow[t]{5}{*}{ BKD2 } & Bakin Dewi & 11.87831 & 9.39741 & 1 & 222.17 & 10.1 & Sandy-soil \\
\hline & & & & 2 & 100.36 & 36.4 & Sandstone \\
\hline & & & & 3 & 18.88 & 3.1 & Clay \\
\hline & & & & 4 & 122.34 & 68.7 & Shale \\
\hline & & & & 5 & - & - & - \\
\hline \multirow[t]{5}{*}{ LWR1 } & Lawaru & 11.93706 & 9.40155 & 1 & 211.01 & 6.4 & Sandy-clay \\
\hline & & & & 2 & 98.74 & 24.4 & Sandstone \\
\hline & & & & 3 & 551.22 & 1.3 & Silt \\
\hline & & & & 4 & 133.54 & - & Shale \\
\hline & & & & - & - & - & - \\
\hline \multirow[t]{5}{*}{ LWR2 } & Lawaru & 11.93481 & 9.39386 & 1 & 218.00 & 7.1 & Sandy-clay \\
\hline & & & & 2 & 128.94 & 22.3 & Sandstone \\
\hline & & & & 3 & 20.14 & 2.4 & Clay \\
\hline & & & & 4 & 133.25 & - & Shale \\
\hline & & & & - & - & - & - \\
\hline \multirow[t]{5}{*}{ NBL1 } & Ngbolung & 11.99184 & 9.41756 & 1 & 188.66 & 9.6 & Sandy-soil \\
\hline & & & & 2 & 113.51 & 21.4 & Sandstone \\
\hline & & & & 3 & 14.25 & - & Clay \\
\hline & & & & - & - & - & - \\
\hline & & & & - & - & - & - \\
\hline \multirow[t]{5}{*}{ NBL2 } & Ngbolung & 11.98498 & 9.41331 & 1 & 220.01 & 7.5 & Sandy-clay \\
\hline & & & & 2 & 114.77 & 20.5 & Sandstone \\
\hline & & & & 3 & 468.55 & 1.6 & Silt \\
\hline & & & & 4 & 123.01 & - & Sandstone \\
\hline & & & & - & - & - & - \\
\hline \multirow[t]{5}{*}{ KMS1 } & Kokumso & 12.05229 & 9.41549 & 1 & 199.66 & 5.8 & Sandy-clay \\
\hline & & & & 2 & 112.27 & 30.5 & Sandstone \\
\hline & & & & 3 & 16.34 & 3.3 & Clay \\
\hline & & & & 4 & 120.05 & - & Sandstone \\
\hline & & & & - & - & - & - \\
\hline \multirow[t]{5}{*}{ KMS2 } & Kokumso & 12.04118 & 9.41537 & 1 & 199.63 & 7.9 & Sandy-soil \\
\hline & & & & 2 & 111.25 & 35.7 & Sandstone \\
\hline & & & & 3 & 21.53 & 1.4 & Clay \\
\hline & & & & 4 & 113.25 & - & Sandstone \\
\hline & & & & - & - & - & - \\
\hline \multirow[t]{5}{*}{ YLW1 } & Yelwa & 12.06990 & 9.41951 & 1 & 223.01 & 6.6 & Sand-clay \\
\hline & & & & 2 & 87.69 & 30.1 & Sandstone \\
\hline & & & & 3 & 18.55 & 1.2 & Clay \\
\hline & & & & 4 & 100.01 & - & Sandstone \\
\hline & & & & - & - & - & - \\
\hline \multirow[t]{4}{*}{ YLW2 } & Yelwa & 12.06553 & 9.41514 & 1 & 228.33 & 8.1 & Sandy-soil \\
\hline & & & & 2 & 110.05 & 36.1 & Sandstone \\
\hline & & & & 3 & 511.20 & 1.1 & Silt \\
\hline & & & & 4 & 120.54 & - & Sandstone \\
\hline
\end{tabular}


Geophysical Characterization of Aquifer Systems Using Vertical Electrical Sounding Method in Demsa, Northeast Nigeria

\begin{tabular}{|c|c|c|c|c|c|c|c|}
\hline & & & & - & - & - & - \\
\hline \multirow[t]{5}{*}{ DWY1 } & Dowaya & 12.07251 & 9.45308 & 1 & 187.44 & 6.3 & Sandy-soil \\
\hline & & & & 2 & 114.22 & 38.6 & Sand \\
\hline & & & & 3 & 14.13 & 3.1 & Clay \\
\hline & & & & 4 & 121.10 & - & Sandstone \\
\hline & & & & - & - & - & - \\
\hline \multirow[t]{5}{*}{ DWY2 } & Dowaya & 12.06405 & 9.44770 & 1 & 210.10 & 9.1 & Sandy-clay \\
\hline & & & & 2 & 108.41 & 37.5 & Sandstone \\
\hline & & & & 3 & 16.77 & 2.3 & Clay \\
\hline & & & & - & - & - & - \\
\hline & & & & - & - & - & - \\
\hline \multirow[t]{5}{*}{ FRA1 } & Farai & 12.11760 & 9.44534 & 1 & 200.14 & 7.2 & Sandy-soil \\
\hline & & & & 2 & 109.64 & 36.9 & Sandstone \\
\hline & & & & 3 & 15.55 & 2.1 & Clay \\
\hline & & & & 4 & 441.26 & - & Shale \\
\hline & & & & - & - & - & - \\
\hline \multirow[t]{5}{*}{ FRA2 } & Farai & 12.11169 & 9.44782 & 1 & 186.55 & 8.1 & Sandy-clay \\
\hline & & & & 2 & 115.46 & 39.8 & Sand \\
\hline & & & & 3 & 18.40 & 2.1 & Clay \\
\hline & & & & 4 & 116.18 & - & Sandstone \\
\hline & & & & - & - & - & - \\
\hline \multirow[t]{5}{*}{ NDS1 } & New Demsa & 12.13877 & 9.42261 & 1 & 211.41 & 7.9 & Sandy-soil \\
\hline & & & & 2 & 117.10 & 34.6 & Sandstone \\
\hline & & & & 3 & 17.45 & 3.4 & Clay \\
\hline & & & & 4 & 121.88 & - & Sandstone \\
\hline & & & & - & - & - & - \\
\hline \multirow[t]{5}{*}{ NDS2 } & New Demsa & 12.12502 & 9.41909 & 1 & 188.97 & 9.2 & Sandy-soil \\
\hline & & & & 2 & 108.55 & 36.8 & Sand \\
\hline & & & & 3 & 16.76 & 3.5 & Clay \\
\hline & & & & 4 & 113.61 & - & Shale \\
\hline & & & & - & - & - & - \\
\hline \multirow[t]{5}{*}{ ODS1 } & Old Demsa & 12.15709 & 9.45903 & 1 & 196.21 & 6.8 & Sandy-clay \\
\hline & & & & 2 & 107.24 & 37.9 & Sand \\
\hline & & & & 3 & 461.28 & 1.9 & Silt \\
\hline & & & & 4 & 123.50 & - & Sandstone \\
\hline & & & & - & - & - & - \\
\hline \multirow[t]{5}{*}{ ODS2 } & Old Demsa & 12.14922 & 9.46185 & 1 & 214.36 & 9.9 & Sandy-soil \\
\hline & & & & 2 & 110.54 & 38.8 & Sandstone \\
\hline & & & & 3 & 18.54 & 1.5 & Clay \\
\hline & & & & 4 & 122.35 & - & Shale \\
\hline & & & & - & - & - & - \\
\hline \multirow[t]{5}{*}{ MBL1 } & Mbula & 12.18834 & 9.51707 & 1 & 233.14 & 8.4 & Sand-soil \\
\hline & & & & 2 & 77.48 & 41.0 & Sand \\
\hline & & & & 3 & 16.64 & 4.1 & Clay \\
\hline & & & & 4 & 133.84 & - & Shale \\
\hline & & & & - & - & - & - \\
\hline \multirow[t]{4}{*}{ MBL2 } & Mbula & 12.18188 & 9.51942 & 1 & 221.34 & 5.5 & Sandy-soil \\
\hline & & & & 2 & 114.22 & 40.3 & Sand \\
\hline & & & & 3 & 17.88 & 3.1 & Clay \\
\hline & & & & 4 & 128.69 & 78.9 & Sandstone \\
\hline
\end{tabular}


Saleh Mustapha Babagana, and Satendra Sharma

\begin{tabular}{|c|c|c|c|c|c|c|c|}
\hline & & & & 5 & 1186.21 & - & Sand/gravel \\
\hline \multirow[t]{5}{*}{ BRG1 } & Borrong & 12.18940 & 9.53563 & 1 & 187.45 & 7.8 & Sandy-clay \\
\hline & & & & 2 & 112.39 & 39.7 & Sandstone \\
\hline & & & & 3 & 668.35 & 1.7 & Silt \\
\hline & & & & 4 & 133.54 & 69.7 & Shale \\
\hline & & & & 5 & 2216.44 & - & Sand/gravel \\
\hline \multirow[t]{5}{*}{ BRG2 } & Borrong & 12.17918 & 9.53622 & 1 & 200.11 & 8.1 & Sandy-soil \\
\hline & & & & 2 & 101.43 & 40.2 & Sandstone \\
\hline & & & & 3 & 15.48 & 1.8 & Clay \\
\hline & & & & 4 & 138.95 & - & Shale \\
\hline & & & & - & - & - & - \\
\hline \multirow[t]{5}{*}{ DLL1 } & Dilli & 12.15862 & 9.53739 & 1 & 176.58 & 8.3 & Sandy-clay \\
\hline & & & & 2 & 108.64 & 40.5 & Sand \\
\hline & & & & 3 & 19.68 & 2.3 & Clay \\
\hline & & & & 4 & 126.84 & - & Shale \\
\hline & & & & - & - & - & - \\
\hline \multirow[t]{5}{*}{ DLL2 } & Dilli & 12.14863 & 9.53304 & 1 & 210.05 & 7.6 & Sandy-soil \\
\hline & & & & 2 & 110.44 & 39.7 & Sandstone \\
\hline & & & & 3 & 18.84 & 1.8 & Clay \\
\hline & & & & 4 & 130.02 & - & Shale \\
\hline & & & & - & - & - & - \\
\hline \multirow[t]{5}{*}{ BNG1 } & Bange & 12.22147 & 9.56418 & 1 & 188.65 & 8.6 & Sandy-clay \\
\hline & & & & 2 & 109.91 & 39.0 & Sandstone \\
\hline & & & & 3 & 533.15 & 3.0 & Silt \\
\hline & & & & 4 & 133.24 & - & Shale \\
\hline & & & & - & - & - & - \\
\hline \multirow[t]{5}{*}{ BNG2 } & Bange & 12.21208 & 9.56523 & 1 & 196.21 & 7.1 & Sandy-clay \\
\hline & & & & 2 & 114.25 & 40.1 & Sand \\
\hline & & & & 3 & 16.33 & 1.4 & Clay \\
\hline & & & & 4 & 124.50 & 71.3 & Shale \\
\hline & & & & 5 & 2222.81 & - & Sand/gravel \\
\hline
\end{tabular}

${ }^{*} \rho=$ Resistivity of layer, $\mathrm{h}=$ thickness of layer. Source: Field survey

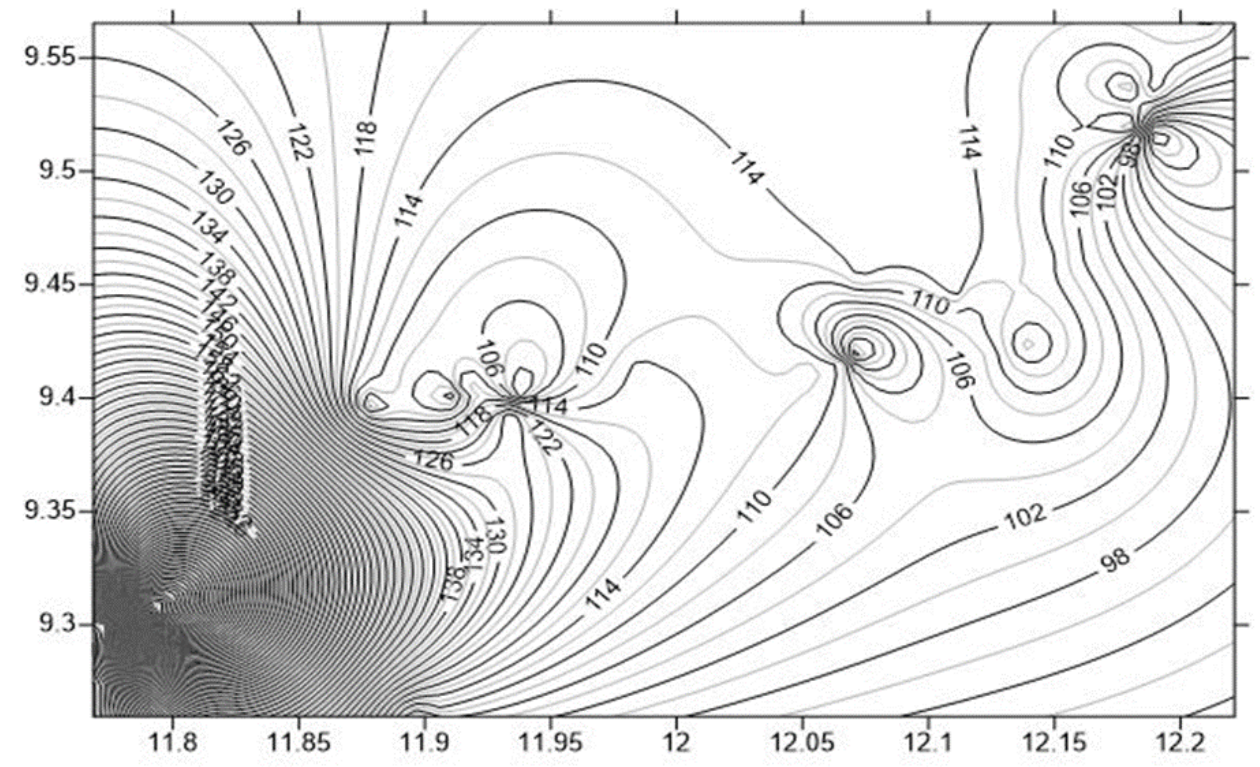

Figure 2: Contour map of resistivity of distribution across the Upper Alluvial Aquifer 


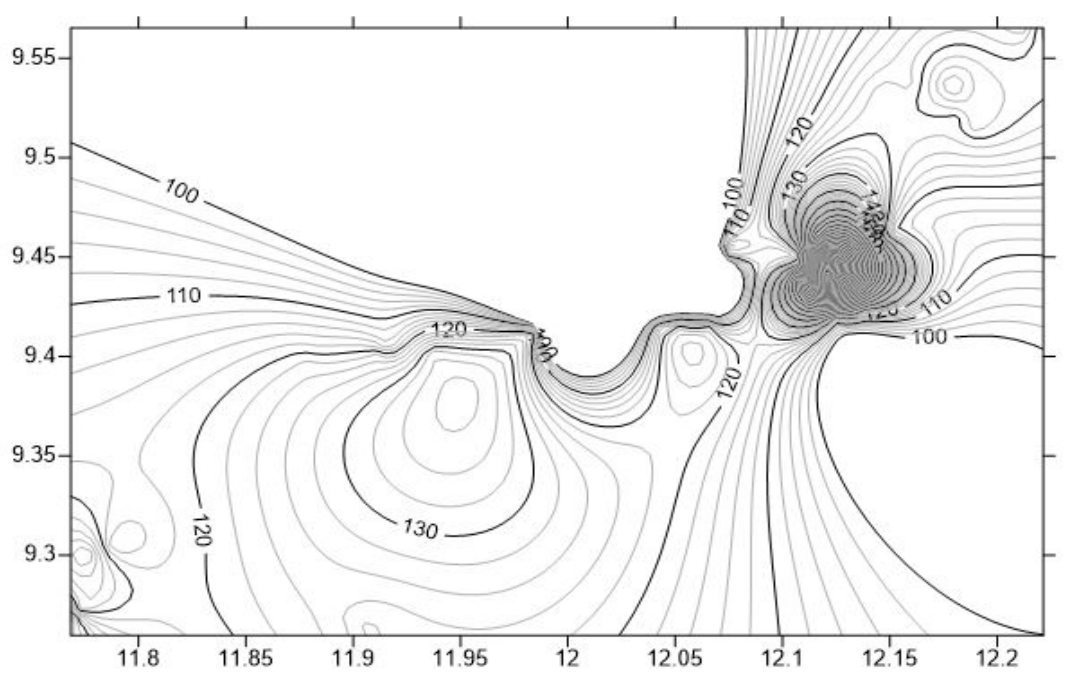

Figure 3: Contour map of resistivity variation across the Deep Aquifer

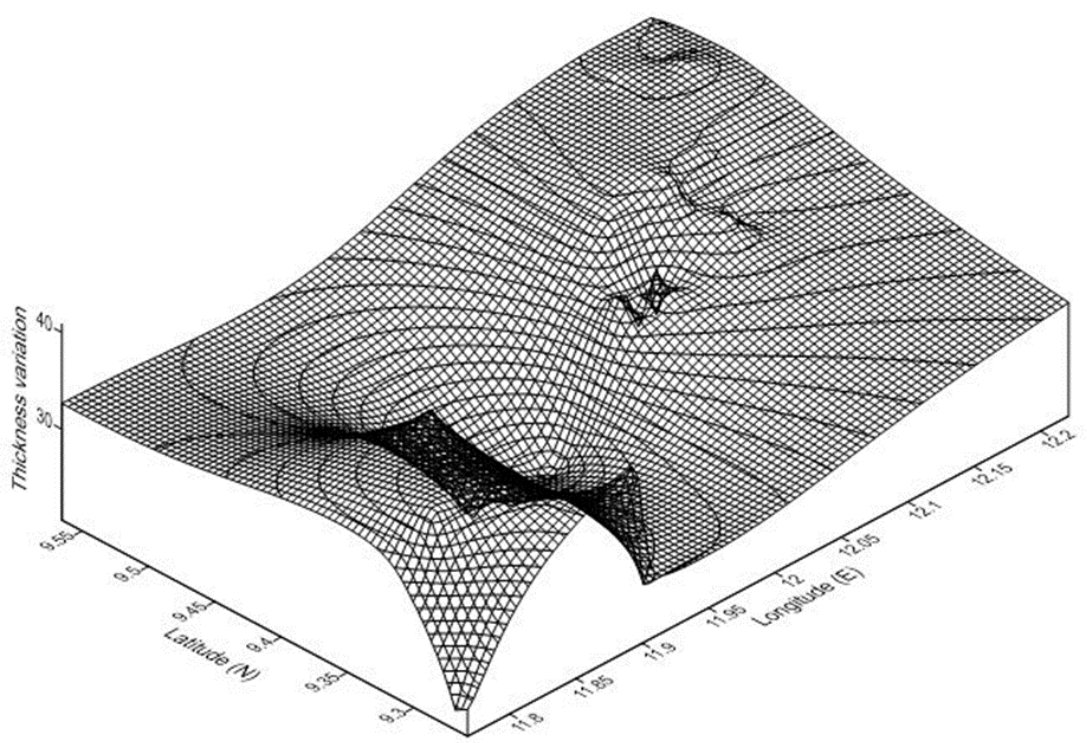

Figure 4: A 3-D representation of thickness variation across the Upper Alluvial Aquifer

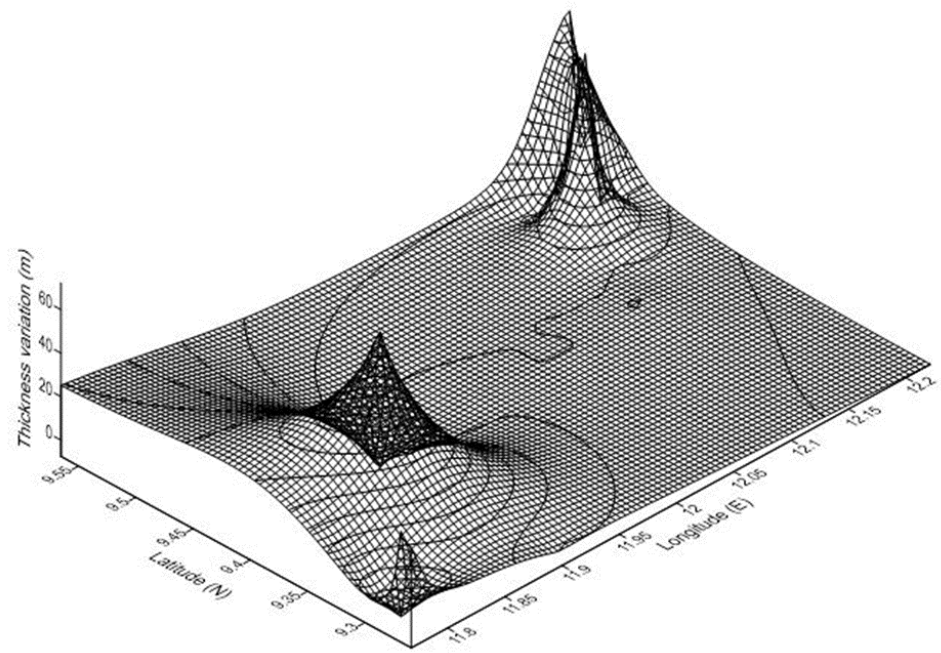

Figure 5: A 3-D representation of thickness variation across the Deep Aquifer International Journal of Research -GRANTHAALAYAH 


\section{CONCLUSION}

From the foregoing results and discussion, the authors of the present study thus concluded that;

1) The hydrogeology of the study area may be controlled by fractures (secondary porosity) developed in sedimentary units.

2) Two aquifers, namely the upper alluvial aquifer and the confined deeper aquifer systems exist in the study area.

3) The two aquifers occur at depths of $20.5-41 \mathrm{~m}$, and 43.8 - $78.9 \mathrm{~m}$ respectively, and are separated by a thin layer of poorly permeable clays and silts, ranged between $1.1-5.3 \mathrm{~m}$ of thickness.

4) The lateral extent of the aquifer systems extend almost evenly across the area. The aquifers' thickness tends to decrease with increase in distance of VES station from the Benue River. This suggested that the aquifer systems are probably recharged by direct escapement of the Benue River.

\section{SOURCES OF FUNDING}

This research received no specific grant from any funding agency in the public, commercial, or not-for-profit sectors.

\section{CONFLICT OF INTEREST}

The author have declared that no competing interests exist.

\section{AUTHORS' CONTRIBUTIONS}

SMB conducted the research, collected the data, analyzed it and drafted the manuscript. SS supervised the research and manuscript.

\section{AUTHOR'S INFORMATION}

SMB (M.Sc.) is an Assistant Lecturer in the Department of Physics, Yobe State University Damaturu, Nigeria.

SS (M.Sc., Ph.D.) is a Professor in the Department of Physics, and Dean, Faculty of Science, Yobe State University Damaturu, Nigeria.

\section{ACKNOWLEDGMENT}

We are grateful to Professor Mala M. Daura, Vice Chancellor, Yobe State University Damaturu, for providing enabling environment for the successful conduct of the present research.

\section{REFERENCES}

[1] Olawuyi, A.K., Abolarin, S.B., 2013. Tertiary - Recent sediments Tertiary volcanics Cretaceous Benin Flank Calabar Flank Jurassic Younger granites Precambrian Basement Major (reference) town 200 km., Niger. J. Technol. Dev., Vol.10, Pages 22-28.

[2] Ginaya, M.A., Yagoob, A.M., 2017. Exploration for Groundwater Aquifers, using Vertical Electrical Sounding (VES) method, in Wad Hamid area - River Nile State, Sudan, SUST Journal of Engineering and Computer $\begin{array}{llllll}\text { Science } & \text { (JECS), } & \text { Vol. } & \text { 18, } & \text { No.3, } & \text { Pages }\end{array}$ http://www.sustech.edu/staff_publications/20171107122231511.pdf

[3] Joseph Olakunle Coker, 2012. Vertical electrical sounding (VES) methods to delineate potential groundwater aquifers in Akobo area, Ibadan, South-western, Nigeria. Journal of Geology and Mining Research, Vol. 4, Pages 35-42. https://doi.org/10.5897/jgmr11.014

https://academicjournals.org/journal/JGMR/article-full-text-pdf/D17EB749903 
[4] Obiefuna, G. I. and Donatus M. O., 2010. Geology and Hydrogeology of Groundwater Systems of Yola Area, Northeast, Nigeria, Journal of Environmental Sciences and Resource Management, Vol. 2, Pages 37-63. https://doi.org/10.13140/RG.2.2.12182.04161

[5] Hubbard, S.S., Rubin, Y., 2000. Hydrogeological parameter estimation using geophysical data: A review of selected techniques. Journal of Contaminant Hydrology, Vol. 45, Issues 1-2, Pages 3-34. https://doi.org/10.1016/S0169-7722(00)00117-0

[6] Maliva, R.G., Herrmann, R., Coulibaly, K., Guo, W., 2015. Advanced aquifer characterization for optimization of managed aquifer recharge. Environ Earth Sci, Vol. 73, Pages 7759-7767. https://doi.org/10.1007/s12665014-3167-z

[7] Slater, L., 2007. Near Surface Electrical Characterization of Hydraulic Conductivity: From Petrophysical Properties to Aquifer Geometries-A Review. Surv Geophys, Vol. 28, Pages 169-197. https://doi.org/10.1007/s10712-007-9022-y

[8] Lachaal, F., Mlayah, A., Bédir, M., Tarhouni, J., Leduc, C., 2012. Implementation of a 3-D groundwater flow model in a semi-arid region using MODFLOW and GIS tools: The Zéramdine-Béni Hassen Miocene aquifer system (east-central Tunisia). Computers \& Geosciences, Vol. 48, Pages 187-198. https://doi.org/10.1016/j.cageo.2012.05.007

[9] Falgàs, E., Ledo, J., Benjumea, B., Queralt, P., Marcuello, A., Teixidó, T., Martí, A., 2011. Integrating Hydrogeological and Geophysical Methods for the Characterization of a Deltaic Aquifer System. Surv Geophys, Vol. 32, Pages 857-873. https://doi.org/10.1007/s10712-011-9126-2

[10] Maliva, R.G., Clayton, E.A. \& Missimer, T.M., 2009. Application of advanced borehole geophysical logging to managed aquifer recharge investigations. Hydrogeol J, Vol. 17, Pages 1547-1556. https://doi.org/10.1007/s10040-009-0437-z

[11] Singha, K., Pidlisecky, A., Day-Lewis, F.D., Gooseff, M.N., 2008. Electrical characterization of non-Fickian transport in groundwater and hyporheic systems. Water Resources Research, https://doi.org/10.1029/2008WR007048

[12] Lesmes D.P., Friedman S.P., 2005. Relationships between the Electrical and Hydrogeological Properties of Rocks and Soils. In: Rubin Y., Hubbard S.S. (eds.) Hydrogeophysics. Water Science and Technology Library, Vol. 50, Pages 87-128, Springer, Dordrecht. https://doi.org/10.1007/1-4020-3102-5

[13] Cardiff, M., Bakhos, T., Kitanidis, P.K., Barrash, W., 2013. Aquifer heterogeneity characterization with oscillatory pumping: Sensitivity analysis and imaging potential, Water Resource Research, Vol. 49, Issue 9, Pages 5395-5410.

https://doi.org/10.1002/wrcr.20356

[14] Bowling, J.C., Zheng, C., Rodriguez, A.B., Harry, D.L., 2006. Geophysical constraints on contaminant transport modeling in a heterogeneous fluvial aquifer. Journal of Contaminant Hydrology, Vol. 85, Issues 1-2, Pages 72 88. https://doi.org/10.1016/j.jconhyd.2006.01.006

[15] Salako Adebayo O. and Adepelumi Abraham A., 2018. Aquifer, Classification and Characterization, in: Aquifers - Matrix and Fluids. https://doi.org/10.5772/intechopen.72692

[16] Meyerhoff, S.B., Maxwell, R.M., Revil, A., Martin, J.B., Karaoulis, M., Graham, W.D., 2014. Characterization of groundwater and surface water mixing in a semiconfined karst aquifer using time-lapse electrical resistivity tomography, Water Resource Research, Vol. 50, Issue 3, Pages 2566-2585. https://doi.org/10.1002/2013WR013991 